\title{
Penerapan Pembelajaran Berbasis Proyek untuk Meningkatkan Assesmen Kompetensi Minimum Siswa
}

\author{
Muhammad Rusli Baharuddin ${ }^{1}$, Fitriani A. ${ }^{2}$, Febriana Nasir ${ }^{3}$ \\ 1) 2) 3) PGSD, Fakultas Keguruan dan IImu Pendidikan, Universitas Cokroaminoto Palopo \\ ${ }^{1)}$ mruslib@gmail.com
}

\begin{abstract}
ABSTRAK
Penelitian ini bertujuan untuk meningkatkan kompetensi minimum siswa melalui penerapan pembelajaran berbasis proyek bagi kelas VA SDN 29 Songka. Penelitian ini termasuk penelitian tindakan kelas. Jumlah subjek dalam penelitian ini 21 siswa dari kelas VA yang terdiri dari 10 siswa perempuan dan 11 siswa laki-laki. Instrumen penelitian yang digunakan adalah tes dan lembar observasi keterlaksanaan dengan teknik pengumpulan data menggunakan tes dan observasi. Hasil penelitian yang dilakukan pada siklus I menunjukkan nilai rata-rata tes numerasi siklus I ialah 59,04 dengan kriteria rendah dan nilai tertinggi 80 dan terendah 30 , sedangkan nilai rata-rata literasi siklus I ialah 61,42 dengan kriteria rendah dan nilai tertinggi 80 dan terendah 30 . Nilai rata-rata numerasi pada tes siklus II ialah 82,85 dengan kriteria sedang dan nilai tertinggi 90 dan terendah 70, sedangkan nilai rata-rata literasi siklus II ialah 85,23 dengan kriteria tinggi dan nilai tertinggi 90 dan terendah 80 . Hasil penelitian ini menunjukkan bahwa model pembelajaran berbasis proyek efektif diterapkan pada pembelajaran siswa baik dilakukan secara daring maupun luring kepada siswa kelas VA SDN 29 Songka.
\end{abstract}

Kata Kunci: Pembelajaran Proyek, AKM, Siswa, Literasi, Numerasi

\begin{abstract}
This study aims to improve the minimum competence of students through the application of project-based learning for class VA SDN 29 Songka. This research includes classroom action research. The number of samples in this study were 21 students from class VA which consisted of 10 female students and 11 male students. The research instrument used was a test and implementation observation sheet with data collection techniques using tests and observations. The results of the research conducted in the first cycle showed the average value of the numeracy test in the first cycle was 59.04 with the low criteria and the highest score was 80 and the lowest was 30 , while the average literacy value in the first cycle was 61.42 with the low criteria and the highest score 80 . and the lowest is 30 . The average value of numeracy in the second cycle test is 82.85 with medium criteria and the highest score is 90 and the lowest is 70 , while the average literacy value in the second cycle is 85.23 with high criteria and the highest score is 90 and the lowest is 80 . The results of this study indicate that the project-based learning model is applied to student learning both boldly and attractively to class VA students at SDN 29 Songka.
\end{abstract}

Keywords: Project Learning, AKM, Student's, Literacy, Numeration

\section{A. PENDAHULUAN}

Program menteri pendidikan tentang pemetaan mutu pendidikan pada seluruh sekolah, Ujian nasional telah diganti menjadi asesmen nasional oleh Kementerian Pendidikan dan Kebudayaan. Kementerian Pendidikan dan
Kebudayaan memutuskan untuk meniadakan ujian nasional dan ujian kesetaraan di tahun 2021. Keputusan tersebut tertuang dalam Surat Edaran Mendikbud Nomor 1 Tahun 2021 tentang Peniadaan Ujian Nasional dan Ujian 
Kesetaraan serta Pelaksanaan Ujian Sekolah dalam Masa Darurat Penyebaran (Covid-19). Surat edaran tersebut ditandatangani Mendikbud Nadiem Anwar Makarim pada 1 Februari 2021 lalu ditujukan kepada gubernur, bupati, dan wali kota di seluruh Indonesia. Dikutip dari website Kemendikbud. Ketentuan tersebut berlaku juga untuk ujian sekolah yang bertujuan sebagai ujian kenaikan kelas siswa. Sekolah dapat menyelenggarakan ujian akhir semester yang dirancang dengan ketentuan yang berlaku untuk mendorong aktivitas belajar yang bermakna, serta tidak perlu mengukur ketuntasan capaian kurikulum secara keseluruhan.

Asesmen nasional di rencanakan mulai pada tahun 2021 dengan nama AN 2021. Bagi siswa, tentu harus paham apa itu asesmen nasional. Untuk asesmen kompetensi minimum (AKM), penjelasan yang di dapatkan dari akun Instagram Badan Penelitian, Pengembangan, dan Perbukuan, Kemendikbud. Pada penelitian kali ini, saya hanya akan meneliti tentang Asesmen kompetensi minimum siswa saja, hal itu dikarenakan poin ini merupakan kompetensi mendasar yang diperlukan semua murid untuk mampu mengembangkan kapasitas diri dan berpartisipasi positif pada masyarakat.

Asesmen kompetensi minimum mengukur literasi membaca dan numerasi sebagai hasil belajar. Asesmen kompetensi minimum dimaksudkan untuk mengukur kompetensi siswa secara mendalam, tidak hanya menguasai konten materi yang diberikan oleh guru. Dalam penyajiannya, asesmen kompetensi umum ini ada beberapa hal tentang permasalahan dari berbagai konteks yang diharapkan mampu diselesaikan oleh murid menggunakan literasi baca dan numerasi yang dimiliki.

Literasi baca didefinisikan sebagai kemampuan dalam memahami, menggunakan, mengevaluasi, serta merealisasikan berbagai jenis teks tertulis. Kementerian pendidikan dan kebudayaan telah menetapkan bahwa masyarakat Indonesia perlu menguasai enam literasi dasar yaitu, (1) literasi bahasa, (2) literasi numerasi, (3) literasi sains, (4) literasi digital, (5) literasi finansial, serta (6) literasi budaya dan kewargaan. Sedangkan Numerasi adalah kemampuan berpikir dalam penggunaan konsep, prosedur, fakta serta alat matematika tetapi maksud ini tidak sama dengan kompetensi matematika. Kemampuan numerasi di sini mencakup keterampilan merealisasikan konsep dan kaidah matematika ke dalam situasi nyata sehari-hari/kontekstual.

Asesmen kompetensi minimum di berbagai sekolah ternyata berbeda-beda, seperti halnya kompetensi minimum yang ada di SDN 29 Songka. Pada tanggal 17 Juni 2021 di kesempatan itu saya mengunjungi sekolah yang nantinya menjadi tempat penelitian saya, saat meminta izin untuk melakukan observasi dan juga meminta izin untuk melakukan peneliti disekolah itu, tidak lupa saya menanyakan beberapa hal kepada kepala sekolah pada saat itu, mengenai beberapa hal yang menjadi bahan tambahan dalam proposal penelitian saya. 
Ternyata, untuk kompetensi minimum siswa tiap kelas disekolah itu berbeda-beda melihat dari tiga faktor; kemampuan siswa, peran guru dan sarana prasarana sekolah. Dalam keterangan lebih lanjut, ternyata penentuan kompetensi minimum siswa itu ditentukan pada tahun ajaran baru, jadi tiap tahun ajaran baru itu selalu berubah melihat situasi dari tiga faktor tadi. Alasan yang paling kuat mengapa kompetensi minimum itu tiap tahun ajaran baru diubah, karena kemampuan tiap siswa berbeda,

Asesmen kompetensi minimum di SDN 29 Songka ini ditentukan dari kurikulum yang berlaku, pencapaian yang sebelumnya dicapai oleh siswa contohnya dengan kelulusan yang dialami oleh siswa disekolah tersebut kemudian dari kenaikan kelas siswa yang nilainya rata-rata mencapai dan juga lebih dari kriteria kelulusan minimal. Untuk kesiapan dari guru sendiri dalam menentukan kompetensi minimum ialah dengan mengikuti perkembangan informasi pemerintah terkait dengan proses pembelajaran yang diberlakukan, sehingga guru bisa menentukan kompetensi minimum yang tepat, terlebih pada saat ini proses pembelajaran masih dalam proses jarak jauh/daring sehingga segala aspek perlu diperhatikan, kemudian juga kesiapan guru untuk mengikuti pelatihan yang diberikan oleh sesama guru disekolah itu, yang telah mengikuti pelatihan kurikulum sebelumnya, karena tentunya dalam pelatihan-pelatih seperti itu tidak semua guru dapat mengikutinya, terbatasnya jumlah perwakilan guru yang diikutkan sehingga guru yang tidakikut pelatihan harus ikut pelatihan yang diberikan oleh guru yang ikut pelatihan kurikulum.

Baharuddin (2018) juga mengatakan bahwa pembelajaran berbasis proyek/kegiatan merupakan model pembelajaran untuk mencapai kompetensi sikap, pengetahuan. Menurut Rakhman (2015) pembelajaran berbasis proyek merupakan metode belajar yang menggunakan masalah sebagai langkah awal dalam mengumpulkan dan mengintegrasikan pengetahuan baru berdasarkan pengalamannya dalam beraktivitas secara nyata

Tujuan yang ingin dicapai dalam penelitian ini adalah untuk meningkatkan kompetensi minimum siswa melalui penerapan pembelajaran berbasis proyek. Berdasarkan tujuan penelitian maka rumusan masalah dalam penelitian yaitu Apakah penerapan pembelajaran berbasis proyek dapat meningkatkan kemampuan Literasi dan Numerasi siswa kelas VA SDN 29 Songka?

\section{B. METODE}

Penelitian ini merupakan penelitian tindakan kelas (PTK) yang bertujuan meningkatkan kompetensi minimum siswa melalui penerapan pembelajaran berbasis proyek. Penelitian dilaksanakan pada semester genap tahun akademik 2020/2021. Subjek Penelitian berjumlah 20 siswa yaitu siswa kelas V SDN 29 Songka Kota Palopo terdiri dari 10 siswa perempuan dan 11 siswa laki-laki.

Tahapan penelitian menggunakan model Kurt Lewin bahwa dalam satu siklus terdiri dari empat langkah pokok yaitu: (1) perencanaan, (2) 
aksi atau tindakan, (3) observasi, dan (4) refleksi. Instrumen yang digunakan penelitian adalah tes Kemampuan numerasi, tes kemampuan literasi, dan lembar observasi keterlaksanaan pembelajaran berbasis proyek.

Teknik analisis data yang digunakan dalam penelitian ini secara deskriptif menggambarkan rata-rata kompetensi minimum siswa dan ketuntasan secara klasikal. Sedangkan indikator keberhasilan dalam penelitian ini yaitu (1) adanya peningkatan rata-rata hasil belajar siswa, (2) secara klasikal, minimal $85 \%$ siswa memperoleh mencapai KKM, dan indikator pendukung adalah keterlaksanaan penerapan model pembelajaran berbasis proyek minimal berada pada kategori terlaksana dengan baik.

\section{HASIL DAN PEMBAHASAN}

Pelaksanaan penelitian dilaksanakan dengan mengikuti tahapan penelitian tindakan kelas yaitu perencanaan, pelaksanaan, observasi, dan refleksi. Setiap tahapan dilaksanakan sesuai dengan tujuan pembelajaran yang akan dicapai.

Penelitian ini bertujuan untuk mengetahui penerapan model pembelajaran berbasis proyek untuk meningkatkan kompetensi minimum siswa kelas VA SDN 29 Songka. Penelitian ini menggunakan 21 siswa sebagai sampel dengan nilai rapor semester II kelas IV dan KKM sebagai pembandingnya. Penelitian ini dilaksanakan dalam 10 pertemuan yang terbagi menjadi 2 siklus, dimana siklus 1 itu ada 4 pertemuan pembelajaran dan 1 tes, begitu pula di siklus 2 ada 4 pertemuan pembelajaran dan 1 tes. Berdasarkan hasil siklus I, Nilai rata-rata tes numerasi siswa kelas VA SDN 29 Songka, diketahui bahwa hasil belajar siswa pada penggunaan model pembelajaran berbasis proyek di numerasi masih rendah, dimana nilai rata-rata yang diperoleh 59,04 dengan nilai terendah 30 dan nilai tertinggi 80 .

Menurut Susanto (2015) mengatakan bahwa hasil belajar siswa adalah kemampuan yang diperoleh siswa setelah melalui kegiatan belajar. Karena biasanya siswa yang berhasil dalam belajar adalah yang berhasil mencapai tujuantujuan pembelajaran dan indikatornya. Sejalan dengan teori itu, Kunandar (2013) mengatakan bahwa hasil belajar adalah kompetensi atau kemampuan tertentu baik kognitif, afektif maupun psikomotorik yang dicapai atau dikuasai peserta didik setelah mengikuti proses belajar mengajar. Begitu pula dengan pendapat Pasiakan (2020) bahwa hasil belajar adalah perubahan perilaku siswa akibat belajar, Sehingga penulis memperbaiki proses pembelajaran yang diberikan dengan membahas lebih rinci tentang materi numerasi yang akan diberikan.

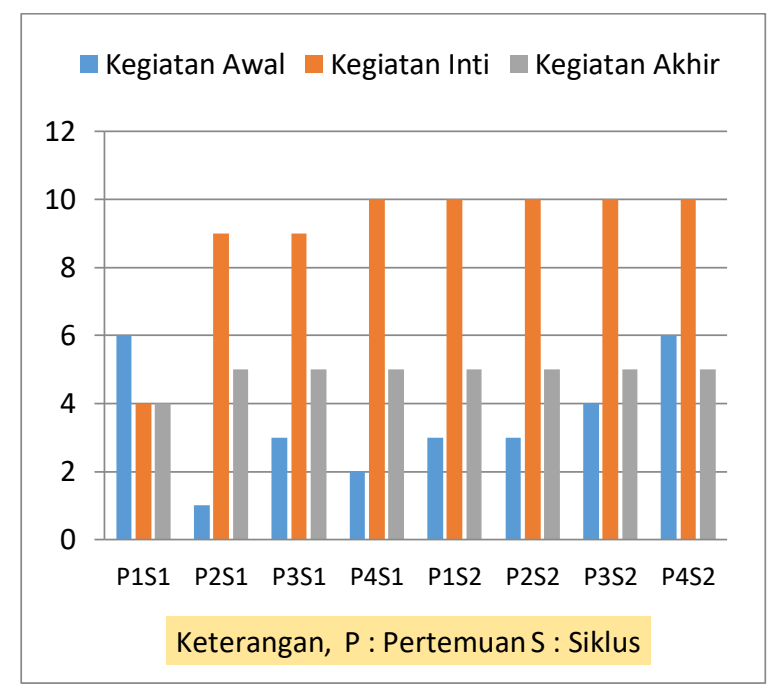

Gambar 1. Implementasi Pembelajaran Proyek 
Berdasarkan hasil siklus I, Nilai rata-rata literasi tes siswa kelas VA SDN 29 Songka, diketahui bahwa hasil belajar siswa pada penggunaan model pembelajaran berbasis proyek di literasi masih rendah, dimana nilai rata-rata yang diperoleh 61,42 dengan nilai terendah 30 dan nilai tertinggi 80 . Menurut Hasnawati (2015) menyatakan bahwa model pembelajaran yang menggunakan proyek sebagai kegiatan proses pembelajaran mencapai kompetensi sikap, pengetahuan dan keterampilan. Sehubungan dengan itu, Sudjana (2013) bahwa hasil belajar adalah hasil kemampuan-kemampuan yang dimiliki siswa setelah ia menerima pengalaman belajarnya. Sehingga penulis menyimpulkan untuk siklus I perlu perbaikan dalam pemberian materi terlebih jika materi itu asing bagi siswa, penggunaan bahasa yang belum dipahami siswa.

Berdasarkan hasil siklus II, Nilai rata-rata tes numerasi siswa kelas VA SDN 29 Songka diketahui mencapai kriteria sedang dengan nilai rata-rata 82,85 dengan nilai tertinggi 90 dan nilai terendah 70, hal ini dicapai tentu karena perubahan/revisi yang sebelumnya dilakukan penulis pada akhir siklus I. Menurut Al-Tabany (2014) mengatakan bahwa model pembelajaran berbasis proyek merupakan pembelajaran inovatif yang berpusat pada peserta didik dan menetapkan guru sebagai motivator dan fasilitator, dimana peserta didik diberi peluang bekerja secara otonom mengonstruksi belajarnya. Sehubungan dengan teori tersebut, Susanto (2013) mengatakan hasil belajar adalah perubahan-perubahan yang terjadi pada diri siswa baik yang menyangkut afektif, dan psikomotorik sebagai hasil dari kegiatan belajar Sehingga penulis meyakini bahwa, jika model pembelajaran berdampak lebih besar pada hasil belajar dari pada materi yang diberikan.

Berdasarkan hasil siklus II, Nilai rata-rata tes literasi siswa kelas VA SDN 29 Songka diketahui mencapai kriteria tinggi dengan nilai rata-rata 85,23 dengan nilai tertinggi 90 dan nilai terendah 80, hal ini dicapai tentu karena perubahan/revisi yang sebelumnya dilakukan penulis pada akhir siklus I. Numerasi adalah kemampuan mengelola bilangan dan data serta mengevaluasi pernyataan yang melibatkan mental dan perkiraan sesuai masalah dan kenyataan Traffer's (2015). Pembelajaran berbasis proyek merupakan model pembelajaran yang menggunakan masalah sebagai langkah awal dalam mengumpulkan dan mengintegrasikan pengetahuan baru berdasarkan pengalamannya dalam beraktivitas secara nyata.

Dari siklus I penulis menemukan bahwa siswa cenderung sulit mengerti tentang materi ajar ataupun soal yang diberikan jika tidak memahami betul apa yang mereka pelajari, sehingga penulis berpikir bahwa pada kelas tinggi seperti ini, siswa sudah harus diberi kesempatan bertanya kepada guru jika kurang paham akan materi atau tugas yang diberikan, ataupun mulai melakukan kerja kelompok sesama teman bermainnya untuk memecahkan masalah yang diberikan. Sedangkan pada siklus 
II, penulis menemukan bahwa rata-rata siswa memahami dengan baik materi dan soal tes yang diberikan, jika selama proses pembelajaran yang dilakukan itu bukan hanya berpusat pada guru, tetapi mulai ada perubahan seperti siswa sudah bisa belajar berdiskusi dengan teman kelompok yang mereka miliki, mulai berani bertanya tentang materi/soal jika tidak dipahami, serta mampu memanfaatkan teknologi yang mereka rasakan saat ini seperti mencari data atau sumber bahan materi di internet dan melakukan diskusi kelompok via whatshaap grup.

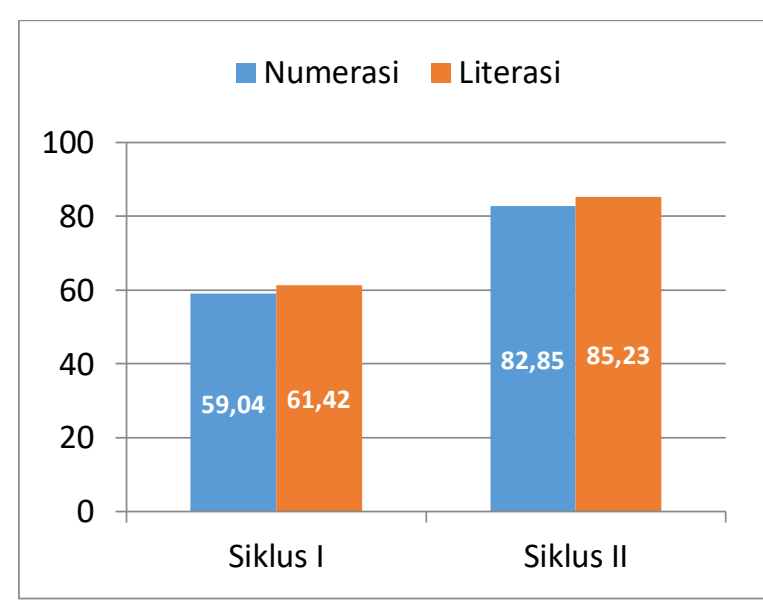

Gambar 2. Penerapan Pembelajaran Berbasis Proyek

Berdasarkan penjelasan tersebut, penulis menyimpulkan bahwa penerapan pembelajaran berbasis proyek berhasil diterapkan ke siswa kelas VA SDN 29 Songka.

\section{PENUTUP}

\section{Kesimpulan}

Kemampuan numerasi dan literasi siswa melalui penerapan pembelajaran berbasis proyek siklus I berada pada kategori rendah yaitu nilai rata-rata kemampuan numerasi yaitu 59,04 dari skor ideal 100 dan nilai rata-rata kemampuan literasi yaitu 61,42 dari skor ideal 100. Sedangkan pada siklus 2 mengalami peningkatan yaitu nilai rata-rata kemampuan numerasi 82,85 dan kemampuan literasi 85,23. Sehingga pada siklus kedua dinyatakan berhasil dengan indikator pencapaian yaitu adanya peningkatan rata-rata kemampuan numerasi dan literasi, secara klasikal mencapai 85\%, dan keterlaksanaan pembelajaran berbasis proyek.

\section{Saran}

Temuan dalam penelitian ini adalah adanya adanya faktor lain yang dapat meningkatkan kemampuan numerasi dan literasi siswa melalui pemanfatan Bahasa Daerah dalam menyajikan konsep. Sehingga penulis merekomendasikan pemanfaatan Bahasa kedaerahan.

\section{DAFTAR PUSTAKA}

Ahmad, S. 2015. Teori Belajar Dan Pembelajaran Di Sekolah Dasar. Jakarta: Prenada Media

Azizah, I. N. (2019). Keefektifan Pembelajaran Berbasis Proyek Ditinjau dari Prestasi Belajar, Kemampuan Berpikir Kritis, dan Kepercayaan Diri Siswa. Jurnal Riset Pendidikan Matematika, 6(2)

Baharuddin, M. R. (2018). Pola Interaksi Belajar Matematika Siswa Berkemampuan Awal Rendah Dalam Pembelajaran Berbasis Proyek. Al-Kharizmi Jurnal Pendidikan Matematika dan Ilmu Pengetahuan Alam, 6(2), 149-156.

Ginting, A. (2014). Esensi Praktis Belajar Pembelajaran. Bandung: Humaniora.

Hanif, F. M. (2018). Meningkatkan Hasil Belajar Jaringan Dasar Model Pembelajaran Berbasis Proyek (Project Based Learning) Siswa Kelas X TKJ 1 SMKN 1BANGKINANG. Jurnal Pendidikan Tambusai, 2(1) 
Hasnawati. (2015). Pendekatan Contextual Teaching and Learning Hubungannya Dengan Hasil Belajar. Staf Pengajar FDBS Universitas Negeri Yogyakarta. Halaman 3. Diakses dari laman Web tanggal 24 September 2021 dari: http://journal.uny.ac.id/index.php/jep/art icle/view/635

Imawan, R. O. (2015). Perbandingan Antara Keefektifan model Guiided Discovery Learning dan Project Based Learning pada Mata kuliah Geometri. Jurnal Pendidikan Matematika, 10(2), 179.

Ismail, R. (2018). Perbandingan Keefektifan Pembelajaran Berbasis Proyek dan Pembelajaran Berbasis Masalah Ditinjau dari Ketercapaian Tujuan Pembelajaran. Jurnal Pendidikan Matematika, 13(2), 181188.

Mulyani, W. (2013). Pengaruh Pembelajaran Berbasis E-Learning terhadap Hasil Belajar Siswa pada Konsep Impuls dan Momentum. Skripsi Program Studi Pendidikan Fisika FTK UIB Syarif Hidaytullah Jakarta.

Pasiakan, S. (2021). Meningkatkan Hasil Belajar Siswa Pada Materi Bangun Datar Melalui Pembelajaran Example Non-Example di Kelas IV SDN 347 Lamasi Pantai (Doctoral dissertation, Universitas Cokroaminoto Palopo).

Rakhman, A. (2015). Implementasi Pembelajaran Berbasis Proyek dengan
Pendekatan Saintifik untuk Meningkatkan Aktivitas dan Hasil Belajar Siswa Pada Pembelajaran IPS di Kelas V Sekolah Dasar.

Sani, R. A. (2021). Pembelajaran Berorientasi AKM. Jakarta: Bumi Aksara.

Sanjaya \& Wina. (2016). Strategi Pembelajaran Berorientasi Standar Proses Pendidikan (Cetakan ke-12). Jakarta: Kencana Prenada Media.

Sara, A. (2014). Peningkatan Kualitas Proses dan Hail Belajar Matematika Melalui Pembelajaran Berbasis Proyek Pada Siswa Kelas VSDN Tidung Kota Makassar. Diakses dari http://eprints.unm.ac.id/1156/

Sucilestari, R \& Arizona, K. (2018). Peningkatan Kecakapan Hidup Melalui Pembelajaran Sains Berbasis Proyek. Prosiding Seminar Nasional Pendidikan Biologi. 436-441.

Sucilestari, R \& Arizona, K. (2018).Pengaruh Project Based Learning pada Mata kuliah Elektronika Dasar terhadap Kecakapan Hidup Mahasiswa Prodi Tadris Fisika UIN Mataram. Konstan Jurnal Fisika dan Pendidikan Fisika, 3(1), 26-35.

Kunandar. 2013. Penilaian Autentik (Penilaian Hasil Belajar Peserta Didik Berdasarkan Kurikulum 2013). Suatu Pendekatan Praktis Disertai Dengan Contoh. Jakarta: Rajawali Pers

Sudjana, N. 2013. Dasar-dasar Proses Belajar Mengajar. Bandung: Sinar Baru Algensindo. 